\title{
THE ROLE OF THE ARMED FORCES
}

IN THE AMERICAS:

CIVIL-MIITARY RELATIONS

FOR THE 21st CENTURY

\author{
BENSOIV LATIN \\ AMERICAN COLLECTION \\ JAN 032000 \\ UNIVERSITY OF TEXAS \\ AT AUSTIN
}

\begin{abstract}
Conference Report
Edited by

Donald E. Schulz
\end{abstract}

April 1998 